NBER WORKING PAPER SERIES

\title{
THE INCIDENCE AND ALLOCATION EFFECTS OF A TAX ON CORPORATE DISTRIBUTIONS
}

David F. Bradford

Working Paper No. 349

NATIONAL BUREAU OF ECONOMIC RESEARCH 1050 Massachusetts Avenue Cambridge MA 02138

May 1979

The research reported here is part of the NBER's research program in Business Taxation and Finance. Any opinions expressed are those of the author and not those of the National Bureau of. Economic Research. 
The Incidence and Allocation Effects of a Tax on Corporate Distributions

\title{
SUMMARY
}

To study the effects of "double taxation" of dividend income (first at the level of the corporation, then at the shareholder level) this paper analyzes a model with a tax on all corporate distributions to equity owners and no other taxes. Contrary to the common view, the tax is shown to have no substitution effect and, in particular, no effect on the corporate choice between debt and equity (via retained earnings) finance. The analysis opens to question certain arguments commonly used to support integration of corporation and individual income taxes via "dividend relief."

\author{
David F. Bradford \\ Woodrow Wilson School of Public \\ and International Affairs \\ Princeton University \\ Princeton, NJ 08544 \\ (609) 452-4804
}




\section{Introduction}

There has recently developed in the United States an increasing interest in the "integration" of individual and corporation income tax systems. As seen in the policy discussions of this issue, the central problem with the existing "classical" system (whereby a tax is levied on corporation profits after payment of interest, independently of distributions), is the double taxation of dividends. Double taxation arises because the income generated by corporate investment financed by equity is taxed once at the level of the corporation, currently at a marginal rate of 46 percent for corporations with significant amounts of income, and then again, at rates ranging from zero to 70 percent on the income tax return of the individual shareholder on the portion of the remainder that is distributed in the form of dividends. The resulting penalty on equity finance, it is argued, distorts the financial and real decisions of corporation. To correct this the usual remedy, which has been extensively adopted in Europe, is to apply some form of "partial integration," which means to apply a tax adjustment which is a function of dividend distributions. Most approaches involve either allowing the corporation to deduct dividend distributions from the corporation income tax base (much as interest payments are deducted) or allowing the shareholder a tax credit which stands in relation to dividends as the corporation income tax stands to corporation income net of tax.

Both of these methods have the effect of eliminating the corporation tax on fully distributed earnings, but they are not otherwise equivalent to the "fu11" integration of corporation and individual income accounts, which is commonly regarded as impractical administratively, even if desirable in principle.1/ The difference between full and partial integration is in the treatment of retained earnings, which are taxed at a flat rate independently of the circumstances of the shareholders under partial integration and at the shareholder's marginal income tax rate under full integration. 
The present analysis suggests that the partial integration approach may have gotten the matter just backwards. The problem on this view is not the extra tax imposed on distributions, but the divergence between shareholder and corporation tax rates on retained earnings. If the market rate of interest is $r$, an individual who pays income tax at marginal rate $m$ earns a rate of return $(1-m) r$ on his savings in ordinary assets. A corporation, on the other hand, is able to accumulate at rate $(1-c) r$ on the same investment, where $c$ is the rate of corporation income tax. The power of compound interest being what it is, we would expect the choice of asset types to be dominated by the difference in the rates of return, even if a price in the form of a tax on distribution must be paid to obtain the favorable rate.

In this paper I consider the incidence and allocation effects of a tax on distributions, as distinguished from a tax on the income of individuals of corporations. To isolate the issue, indeed, I abstract from the taxation of income, as well as from uncertainty, nonlinearity of tax rules and multiplicity of individual tax regimes. This paper analyzes the behavior of a system with a flat rate tax on corporate distributions to shareholders and no other taxes. It is thus concerned with a kind of polar case of the double taxation of dividends.

In view of the abstraction from uncertainty, it might appear to be an open and shut case that imposing a tax on distributions will lead to a flight to the corner solution of all-bond finance. Or at least, if this is not optimal, it would appear obvious that good financial policy toward equity calls for retained earnings only, so that stockholders can take their returns in untaxed capital gains. The conclusion of the analysis is that neither of these results obtains. While the issue of new equity may become unattractive (unless this form of negative distribution is subsidized at the same rate that positive distri- 
butions are taxed), all those financial plans involving non-negative distributions, over which indifference prevails in the absence of the tax, continue to be indifferent. The all-debt policy acquires no special place, nor are dividends discouraged in favor of retained earnings.

The latter point is based upon a careful treatment of the determination of the value of equity claims. For if, as is often assumed, a dollar of retained earnings leads to a one dollar increase in the market value of equity, shareholders could obtain their returns free of the tax on distributions. The conclusion of the present analysis, based on a rational expecations model of asset pricing, is that an extra dollar of retained earnings (with corresponding reduction in borrowing) increases the value of equity by one minus the rate of distributions. This is why shareholders are indifferent between dividends and retained earnings.

Intuitive Explanation of the Results. It may assist understanding of the results to consider the analogy of the tax on distributions with a tax on all withdrawals from savings accounts opened before some specified date in the past. Were they bought and sold as are bonds, the market value of such accounts would presumably fall upon imposition of the tax, to one minus the tax rate times their face value "replacement cost." The tax once in place, there is no particular incentive for existing account owners to accelerate the pace of withdrawals; a growing value of balances in such accounts (due to accumulating interest), and, therefore, a growing absolute divergence between market and replacement values, is fully consistent with optimizing behavior.

In the analysis presented here, the corporate "vessel" is the analogue of the savings account, and the tax on distributions the analogue of the tax on withdrawals. The tax is the price that must be paid to get cash out of the corporation. Like the hypothetical tax on bank accounts, it would be necessary for a 
of a surprise, for it to find any base to subject to tax. The usual analysis of the corporation income tax, in effect, assumes it is being imposed before the system "starts up." The discussion below illustrates how profound a difference it may make to examine instead a tax on dividends imposed on a system already in existence.

Implications. Our conclusion about equity valuation has some significant consequences. One implication is that along an equilibrium path the total value of the firm--the sum of market values of its debt and equity--will depend on the financial policy of the firm, which is indeterminate, even though the firm's real capital stock will be determinate. The larger the fraction of equity finance, the lower will be the market value of the firm (which will always be less than or equal to its replacement cost if the firm is not permitted to be a net creditory).

A second implication of the equity valuation result is that an unanticipated change in the rate of taxation of distributions affect the market value of existing equity claims, and, hence, the wealth of their holders. For a given rate of interest and for given corporate indebtedness and capital stock, the value of equity is simply proportional to one minus the rate of tax on distributions .

Not only does the tax have no effect on corporate financial policy, it also leaves the investment criterion unchanged. This is not quite the same as leaving investment unchanged since wealth effects of the tax may influence the path of the economy. This point is borne out in the model developed here, in which the potential forms in which wealth can be held are corporate debt and equity, and government debt. 
The inclusion of government debt in the model is not fortuitous. Since corporate financial policy is indeterminate, so also is the flow of government receipts from the distribution tax. In the model the proceeds of the tax are used to retire government debt. The equilibrium conditions of the model include a term reflecting the present value of receipts from the distribution tax, comparable and opposite in sign to the quantity of government debt.

In the model presented one can readily analyze the incidence of a change in the tax parameter without an offsetting change in either other taxes or government exhaustive expenditure. An increase in the tax rate causes a loss in value of existing equity and, therefore, influences the future course of the economy in ways that are in principle determinate. Of particular interest is an increase in tax rate accompanied by a one-time government expenditure, financed by an increase in government debt sufficient to offset the tax increase. The incidence of this combination is confined wholly to the wealth loss of holders of equity at the time. There is no deadweight efficiency loss, and no burden to be the subject to subsequent concern.

This explains the remark above to the effect that the partial approach to integration may be correcting the wrong problem. While the present analysis is far too simple to support policy conclusion, it does suggest that insofar as partial integration amounts to eliminating a tax on distributions, it may result primarily in windfall wealth redistributions, reversing the, by now, irrelevant wealth changes that occurred when the tax was introduced, while leaving the features of the tax system giving rise to ineffiiency.

Connection with the Existing Literature. The approach taken here bears some similarity to that taken in recent papers by Joseph Stiglitz (1973) and Mervyn King (1974) which show that the relationship between income tax rules and 
optimal corporation financial and investment policies is more complex than had been previously understood.2/ By analyzing the corporation's choices as part of a multi-period optimization problem, these authors are able to treat consistently the interactions between individual and corporation income tax systems. Both papers conclude that the optimal financial structure may be indeterminate, given certain relationships among the relative rates of taxation of corporate income, corporate distributions, interest payments and capital gains, the history of the corporation (in Stiglitz's analysis), and expected future values of the tax parameters (in King's analysis). For these cases and for a wide further class as well, the corporation's real investment decisions are unaffected by the taxes.

The present paper differs from these predecessors in its explicit attention to general equilibrium, including equilibrium in the asset market, in an infinite-horizon world with rational expectations. Stiglitz devotes little attention to the question of asset valuation. As far as the question of financial structure is concerned, his analysis best described as a theory of the small, closely held corporation. His results turn on the tax-technical matter of whether a corporate distribution is classified as a "return of capital" (and hence free of individual income tax--the tax on distributions). The corporations accounting for the vast bulk of corporate assets in the United States rarely approach the condition of having distributions which qualify as return of capita1. As a consequence, the necessary conditions for optimality of financial policy (Stiglitz 1973, p. 13) are fulfilled empirically by the large public corporations, essentially permanent, horizon-less institutions, constituting the major share of the corporate sector. A different theory is needed to explain their behavior, and it can probably neglect the special treatment of return of capital, as is done here (and in King). $\underline{3}$ / 
Whereas, Stiglitz in his paper looks at the corporation as the vehicle of an individual investor, King views the problem of corporate decisionmaking as that of maximizing the present market value of equity. His paper can be regarded as a theory of the market value of a firm setting financial and investment policies optimally with respect to present and expected tax parameters. Presumably because his analysis is in a partial equilibrium setting, King does not concern himself with the wealth changes implied by changing tax parameters which are given special attention here. However, the neutrality results described here can be derived as a special case of King's model, and it might be interesting to impose his richer structure of tax institutions on the general equilibrium model examined here.4/ For present purposes, however, the single tax on distributions is sufficient.

Outline of the Paper. Section 2 below contains the formal description of the model economy, including the equilibrium concept employed. Section 3 derives a solution of the model. Section 4 contains a discussion of the results summarized above, while Section 5 contains concluding remarks.

2. Formal Model of Rational Expectations Equilibrium with a Tax on Distributions.

The model underlying the analysis is in the Samuelson (1959) consumption loan

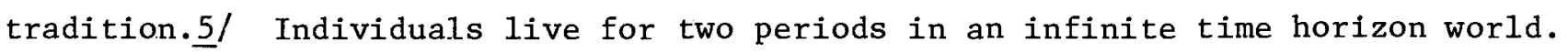
In the first life-period each individual works (offering one unit of labor inelastically), consumes, and saves for retirement. "Retirement" describes the second life-period, when each individual dissaves and consumes, leaving nothing to his heirs. 


\section{$-8-$}

All production takes place in the single corporation which behaves as a price taker. Production conditions are described by a neoclassical production function of capital and labor employed, with constant returns to scale. The capital available to the corporation in any period is inherited from the previous period and is thus fixed in amount before the time of actual production. The output of a period may either be consumed or frozen into infinitely durable capital. Investment is regarded as reversible (defrosting is possible).

Savings may be held in three forms, bonds issued by the corporation shares of its common stock, or bonds issued by the government. A given generation of individuals acquires these financial assets at the end of its first life-period, after production for that period has been completed, and after the investment plans of the corporation have been realized.

The holders of its common stock "own" the corporation. The owners at the beginning of a period control that period's production and the real investment which determines the amount of capital which will be available for use in production at the beginning of the next period. The owners of the firm at the beginning of a period specify as well the financial policy for that period, which means they set the amount of funds to be distributed to themselves as dividends and the amount of corporate borrowing.

Although the model does not contain stochastic elements it is necessary for the agents in the model world to make decisions based on expectations about the future. The concept of equilibrium employed requires that, execpt for such rude shocks as a change in the tax parameter, agents' expectations be fulfilled. This is made more precise below. 


\section{Principal Variables}

L : total number of labor units available for application during the period (equals the number of individuals born in the period, exogenously given).

$\mathrm{K}$ : stock of corporate capital at the beginning of the period (used for production during the period).

D : total distribution made by the corporation during the period.

$V$ : "ex dividend" value of corporate equity, that is, the value at the end of a period, after production is complete and distribution and investment decisions have been made.

B : total corporate indebtedness at the beginning of the period, which must be repaid during the period.

${ }_{B} g$ : total stock of government indebtedness at the beginning of the period, which must be repaid during the period.

$F(K, L)$ : the production function, characterized by constant returns to scale.

Lower case versions of the variables defined above represent individual, rather than aggregate levels.

w : wage, expressed in terms of output (output is taken as numeraire throughout). 
$r$ : the interest rate; a bond payable next period sells for $1 /(1+r)$ in the current period.

$t$ : rate of tax on corporate distributions to stockholders.

For any variable, $x$, let $x_{+}, x_{++}$, etc., represent $i t s$ value in succeeding periods; $\mathrm{x}_{-}$its value in the preceding period. Let $\mathrm{x}_{+}^{\mathrm{e}}$ denote the value of $\mathrm{X}$ expected to obtain in the next period, $\left(\mathrm{x}_{+}^{\mathrm{e}}\right)_{+}^{\mathrm{e}}$ the expected value of next period's expected value, and so on.

\section{The Formal Structure of the Mode1}

The formal structure of the model is as follows:

Agents. There are three classes of agents. The "young" consists of $\mathrm{L}$ identical individuals, each of whom supplies one unit of labor inelastically and chooses first life-period consumption, $c^{1}$, corporate bond holding, $b_{+}$ government bond holding, $b_{+}^{g}$, and fraction, $s$, of the ownership in the corporation, to maximize a utility function, $u\left(c^{1}, c^{2}\right)$.

The "old" consists of L_ identical individuals. The representative member of this group runs the corporation he bought in his youth, choosing the quantity of labor, $\mathrm{L}^{\mathrm{D}}$, supply of bonds, $\mathrm{B}_{+}$, and capital stock to be carried into the next period, $\mathrm{K}_{+}$. These imply a level of corporate distributions, $\mathrm{D}$. All of these are chosen to maximize second life-period consumption, $c^{2}$.

The "government" is usually simply a cash flow manager. It redeems expiring bonds for $\mathrm{B}^{\mathrm{g}}$ with the proceeds of sale of new bonds, $\mathrm{B}_{+}^{\mathrm{g}} /(1+r)$, plus receipts from the tax on corporate distributions, tD. 
Markets. There are five markets, for labor, corporate bonds, government bonds, equity and goods. In each period the prices of labor and bonds (government and corporate bonds are assumed perfect substitutes) and the relationship between corporate financial and investment decisions and equity value adjust to clear the markets. The equilibrium quantities in any period will depend on the capital stock, outstanding debt obligations and the size of the new generation, all of which are either exogenous or determined in the preceding period. In turn the market clearing condition determines the values of capital stock and bond obligations carried into the next period.

State Variables. The conditions inherited from the past, affecting the current path of the economy, are the capital stock, the corporate debt obligation, and the government debt obligation. In addition, the labor supply, exogenously determined, influences the equilibrium. The state of the economy, predetermined in any period is thus described by a vector, $\left(K, B, B^{g}, L\right)$.

Endogenous Variables. The value of the ownership claim on the corporation is going to depend upon the capital stock and the debt obligation being carried forward into the next period. These are two of the three variables which must be determined by the corporation's owners, and we may characterize them as determining the "quality" of the equity claim which the owners propose to sell. Quality is thus described by the pair, $\left(\mathrm{K}_{+}, \mathrm{B}_{+}\right)$.

In addition to the two conventional prices, the wage, $w$, and the interest rate, $r$, there is a "valuation function," relating the quality of equity, as set by the corporation's owners, to its price. $V\left(\mathrm{~K}_{+}, \mathrm{B}_{+}\right)$represents the value of a 100 percent interest in the corporation. 
Expectations about future prices and equity valuation are also determined endogenously. All individuals are assumed to have identical point expectations, represented by a vector, $\left(w_{+}^{e}, r_{+}^{e}, v_{+}^{e}\right)$.

Temporary Equilibrium. A temporary equilibrium, conditional on the state of the economy and expectations, is a balancing combination of prices and a valuation function, together with a specification of the quality of equity and amount of government indebtedness, such that all markets clear. Thus, a temporary equilibrium may be described by a vector, $\left(w, r, V, K_{+}, B_{+}, B_{+}^{g}, L\right)$, such that the capital stock and bond obligations, $\mathrm{K}_{+}, \mathrm{B}_{+}, \mathrm{B}_{+}^{\mathrm{g}}$ are compatible with all markets clearing at prices $(w, r)$, and equity valuation function, V, with employment level L.

Evolution. The evolution of the economy is determined in part by the exogenous change in population, from $\mathrm{L}$ to $\mathrm{L}_{+}$, assumed describable by a first order difference relationship. $6 /$ Because of this assumption it will be taken for granted below that knowing the relationship between a current endogenous variable and $\mathrm{L}_{+}$ is equivalent to knowing that between it and $L$. The remaining state variables are determined by the temporary equilibrium market clearing conditions. In general, these will not uniquely determine the quantities involved. In particular, for the system under study, the level of corporate indebtedness carried forward will generally be arbitary, since corporate financial policy will be a matter of indifference.

Rational Expectations. It will be assumed that expectations are "rational" in the sense introduced to the economics literature by Muth (1961). In the present, non-stochastic model, I take the notion of rationality of expectations to encompass two properties. The first is that rational expectations are correct in that in an economy evolving according to a sequence of temporary equilibria, each dependent upon that period's expectations, each period's expectations will be ful- 
filled in the following period. The second property embodies the idea that if two economies are identical in structure and have reached the same state (where the calendar date is not considered part of the state description), their agents should have the same expectations. This property is intended to represent the notion that phenomena such as the tulip bulb mania are pathological. We want expectations to be linked to the underlying economic reality and hence wish to rule out those that are self-fulfilling if prices continue to appreciate, regardless of underlying economic reality. Expectations satisfying the second property can be described as stationary functions of state variables.7/ Note that there is no guarantee that rational expectations exist for an economic system, nor that if they exist they are unique.

\section{A Solution to the Model}

In this section we describe the behavior of the model economy in an equilibrium with rational expecations. This means writing down expressions for the endogenous variables, including expectations, in terms of the state variables, satisfying the definitions of equilibrium with rational expectations: given expectations, markets clear and expectations are correct.

Throught the following discussion of equilibrium it is assumed that the tax parameter, $t$, is constant. One-time policy changes are assumed to be unexpected. Furthermore, non-negativity constraints are ignored. 1 /

The natural way to proceed would be to solve for the temporary equilibrium as a function of the agents' expectations and then to seek a form of expectations that is self-fulfilling. Given the large set of possible expectations (recall that the valuation of equity is represented by a function) this is rather complicated. Instead, we shall take the approach of first developing a reasonable 
conjecture about the temporary equilibrium under rational expectations, then describing the associated scheme of expectations, and finally showing that the optimizing behavior of agents holding those expectations will produce the originally conjectured temporary equilibrium.

Therefore, we follow a somewhat artificial sequence, in which the first step is to write down equations which are asserted to determine the endogenous variables other than expectations. We then write down the equations asserted to determine the expectations from the state variables, and show that when the system evolves according to the rules described in the previous section these expectations are correct. Only then do we go through the steps to show that if the agents have these expectations, their optimizing behavior will indeed lead to a temporary equilibrium with the originally asserted relationship between state variables and current prices and quantities.

\section{Endogenous Variables in Temporary Equilibrium}

The strict logic of the argument does not call for any discussion of equilibrium until step three. However, the asserted relationships between current prices and quantities and state variables in temporary equilibrium with rational expectations will be recognizably conditions of competitive market clearing, and will be more readily understood if discussed in these terms.

Equations (1) and (2) below, with their associated definitions, (3) and (4), describe wage and interest rate determination by labor and goods market clearing. The function $K^{*}$ defined in (3) and evaluated at $\left(r, L_{+}\right)$gives the capital stock which equates the rate of interest to the marginal product of capital at full employment in the next period. This is the amount of capital which will be carried forward into the next temporary equilibrium.' Problem (4) is a lifetime utility maximization problem of a representative individual with lifetime consumption preferences described by $u$ when the rate of return on savings is $r$ and with 
wealth equal to $w$, the wage reward for one unit of labor. Equation (1) is the condition of equality of wage and marginal product of labor at full employment. Expression (2) specifies that total savings of the young generation equals the capital stock carried forward plus the government debt less a term reflecting the potential government receipts from the tax on distributions.

$$
\begin{aligned}
& w=F_{2}(K, L) \\
& \left(w-c^{1}(r, w)\right) L=K *\left(r, L_{+}\right)+B^{g}-t(F(K, L)-w L-B+K)
\end{aligned}
$$

Here $F_{i}$ denotes the derivative of $F$ with respect to its $i$ 'th argument; $\mathrm{K} *\left(\mathrm{r}, \mathrm{L}_{+}\right)$is defined by:

$$
F_{1}\left(K *\left(r, L_{+}\right), L_{+}\right)=r
$$

and $c^{1}(r, w)$ solves the problem:

$$
\begin{aligned}
& c^{1,}, c^{2} u\left(c^{1}, c^{2}\right) \\
& \text { subject to } c^{1}+\frac{c^{2}}{1+r}=w
\end{aligned}
$$

In the model world the amount the representative young person will offer for a share in the firm will depend on the expected sum of corporate distribution and resale proceeds in the next period. It is natural to conjecture that equilibrium valuation of equity will be related to the potential net-of-tax withdrawals from the firm. Since all withdrawals are taxed, the expected net withdrawal obtained if no debt is issued in the next period (in effect "closing the account") would be the obvious basis for evaluation. This is given by: 


$$
(1-t)\left(F\left(K_{+}, L_{+}\right)-w_{+}^{e} L_{+}-B_{+}+K_{+}\right)
$$

Since there is no uncertainty, this sum will be discounted at the rate interest, $r$, giving us:

$$
V\left(K_{+}, B_{+}\right)=\frac{(1-t)}{(1-r)}\left(F\left(K_{+}, L_{+}\right)-w_{+}^{e_{+}}-B_{+}+K_{+}\right)
$$

Recall that our objective is to specify the endogenous variables as functions of state variables. Noting that $r$ has been described as a function of state variables by (1)-(4) we must only anticipate the rational expectations of wages to write $\mathrm{V}$ in the required form. The expected wage level will presumably clear the labor market when the endogenously determined capital stock is available. Hence, we conjecture, by analogy with (1):

$$
\mathrm{w}_{+}^{\mathrm{e}}=\mathrm{F}_{2}\left(\mathrm{~K} *\left(\mathrm{r}, \mathrm{L}_{+}\right), \mathrm{L}_{+}\right)
$$

so that the equity valuation function is itself expressed as a function of state variables by:

$$
V\left(K_{+}, B_{+}\right)=\frac{(1-t)}{(1-r)}\left(F\left(K_{+}, L_{+}\right)-F_{2}\left(K *\left(r, L_{+}\right), L_{+}\right) L_{+}-B_{+}+K_{+}\right),
$$

which says that the value of equity is equal to the discounted value of the after-tax proceeds of distributing in the next period all of the anticipated resources of the corporation, after paying off the debt.

These equations determine the two prices and the equity valuation function. The capital stock carried into the next period will be given by $\mathrm{K}^{*}\left(\mathrm{r}, \mathrm{L}_{+}\right)$. It remains to determine $\mathrm{B}_{+}$and $\mathrm{B}_{+}^{\mathrm{g}}$. The stock of debt the young will want to hold, with present value $\left(B_{+}+B_{+}^{g}\right) /(1+r)$, will depend on their evaluation of equity. 
The aggregate portfolio value of the young is determined by their consumption decision. Therefore, we have:

$$
\left(w-c_{1}(r, w)\right) L=V\left(K^{*}\left(r, L_{+} B_{+}\right)+\left(\frac{B_{+}+B_{+}^{G}}{1+r}\right) .\right.
$$

It turns out that any combination of $\mathrm{B}_{+}$and $\mathrm{B}_{+}^{\mathrm{g}}$ satisfying (8) is compatible with equilibrium. Associated with a larger value of $\mathrm{B}_{+}$will be lower values of $\mathrm{V}$ and $\mathrm{B}_{+}^{\mathrm{g}}$. Note that condition (8), together with (7) implies:

$$
\mathrm{tB}_{+}+\mathrm{B}_{+}^{\mathrm{g}}=\text { constant }
$$

where the constant depends upon $r$, w and $\mathrm{L}_{+}$.

\section{Rationa1 Expectations}

Expression (6) relates the expected wage to the labor force in the next period and the capital stock that would be optimally employed with the labor if capital services were directly marketed and had a price equal to $r$, the rate of interest. The value of $r$ is determined from state variables by (1)-(4). The remaining expectations of interest rate and equity valuation function are, like (6), obtained by adding the expectation superscript to the appropriate temporary equilibrium condition and making use of the functional relationship between state variables and current prices and quantities as already described.

The value of $r_{+}^{e}$ is obtained by combining (1)-(4), (6), (9) and (10):

$$
\begin{aligned}
& \left(w_{+}^{e}-c^{1}\left(r_{+}^{e}, w_{+}^{e}\right)\right) L_{+}=K^{*}\left(r_{+}^{e}, L_{+}\right)+B_{+}^{g}-t\left(F\left(K^{*}\left(r, L_{+}\right), L_{+}\right)-\right. \\
& \left.\mathrm{w}_{+}^{\mathrm{e} \mathrm{L}_{+}}-\mathrm{B}_{+}+\mathrm{K} *\left(\mathrm{r}, \mathrm{L}_{+}\right)\right) \text {. }
\end{aligned}
$$

Similarly, the expected valuation function is given by: 


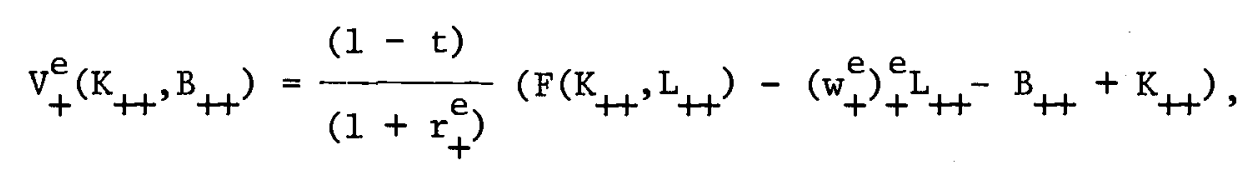

where

$$
\left(\mathrm{w}_{+}^{\mathrm{e}}\right)_{+}^{\mathrm{e}}=\mathrm{F}_{2}\left(\mathrm{~K} *\left(\mathrm{r}_{+}^{\mathrm{e}}, \mathrm{L}_{++}\right), \mathrm{L}_{++}\right)
$$

The Correctness of Expectations. Given our approach to developing the expectations formulae, it will be no surprise that they will be correct if the next period's equilibrium is described by relationships (1)-(4), (7) and (8), suitably updated. For example, since $\mathrm{K}_{+}=\mathrm{K}^{*}\left(\mathrm{r}, \mathrm{L}_{+}\right)$, condition (6) implies that $\mathrm{w}_{+}=\mathrm{w}_{+}^{\mathrm{e}}$. Similar reasoning implies that $\mathrm{r}_{+}=\mathrm{r}_{+}^{\mathrm{e}}$ and $\mathrm{v}_{+}=\mathrm{v}_{+}^{\mathrm{e}}$.

\section{The Temporary Equilibrium is the Right One}

It remains to show that if the agents form their expectations in the way described, then equations (1)-(4), (7) and (8) indeed characterize a temporary equilibrium. For this we need to derive the demands and supplies of the agents on the various markets and test for market clearing.

The budget constraints of the young and old generations together with the behavioral rule ascribed to the government imply that the excess demands on these five markets are dependent in the usual Walrasian fashion: clearing of four markets implies clearing of the fifth. This may be most easily seen if we for a moment regard the old generation as two sets of agents: stockholders and corporation managers. The budget balance requirement for the young implies that the sum of the values of their excess demands for the five "commodities" (1abor, corporate bonds, government bonds, equity and goods) must be zero. The sum of the values of excess demands of stockholders will be $B+B^{g}+(1-t) D$, as the old generation cashes in its old bonds (which are not commodities marketed in 
the current period) and collects the after-tax proceeds from the corporate distribution. The sum of values of the excess demands of the corporation will be $-B-D$, as it pays off the inherited debt obligation and makes its distribution. For the government, which supplies new debt to cover the difference between old debt and tax receipts, the sum of excess demands is $-B^{g}+t D$. It may be verified that the four classes of excess demands aggregate to zero. Hence, if market excess demands of four of the five commodities are zero the fifth market excess demand must be zero as well.

Excess Demands of the Young. Consider first the young generation. They anticipate solving the problem of optimally managing the corporation as owners of its equity, with quality given by $\left(\mathrm{K}_{+}, \mathrm{B}_{+}\right)$. That is, they anticipate solving:

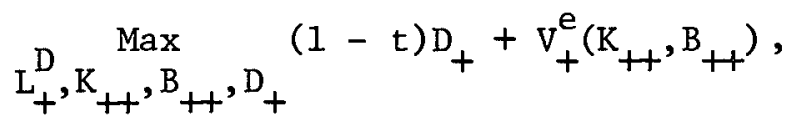

where $D_{+}$is the distribution they make to themselves from the corporation:

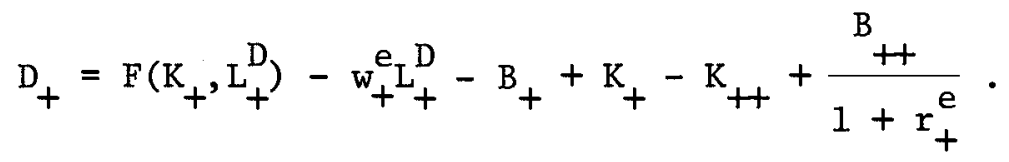

Substitute (11), (12) and (14) into the maximand, thereby, eliminating the decision variables $\mathrm{B}_{++}$and $\mathrm{D}_{+}$, and calculate first order conditions for a solution with respect to the remaining two. The anticipated labor demand satisfies:

$$
\mathrm{F}_{2}\left(\mathrm{~K}_{+}, \mathrm{L}_{+}^{\mathrm{D}}\right)=\mathrm{w}_{+}^{\mathrm{e}}
$$

Using (6) and the assertion (3) that $\mathrm{K}_{+}=\mathrm{K}^{*}\left(\mathrm{r}, \mathrm{L}_{+}\right)$(used in implicitly determining $w_{+}^{e}$ according to rational expectations), we conclude that: 


$$
\mathrm{L}_{+}^{\mathrm{D}}=\mathrm{L}_{+}
$$

The first order condition for optimality with respect to $\mathrm{K}_{++}$in (13) is:

$$
\mathrm{F}_{1}\left(\mathrm{~K}_{++}, \mathrm{L}_{++}\right)=\mathrm{r}_{+}^{\mathrm{e}}
$$

Euler's Theorem applied to the constant returns to scale production function implies that, given the asserted relationships between state variables and current endogenous variables, the solution of (13) can be expressed as:

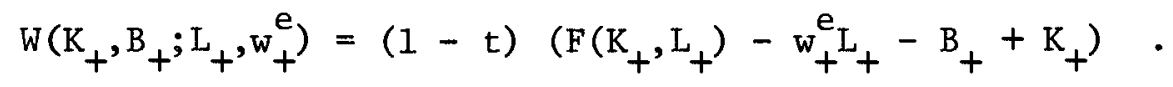

In (18) the determination of $\mathrm{L}_{+}$and $\mathrm{w}_{+}^{\mathrm{e}}$ as a function of current state variables is implicitly taken for granted.

Now imagine that a Walrasian auctioneer has called off wages, interest rate and valuation function and the existing owners of the corporation have set $\mathrm{K}_{+}$and $\mathrm{B}_{+} \cdot$ The representative young person now solves the lifetime consumption maximization problem:

$$
c^{1}, c^{2}, b_{+}, b_{+}^{g}, s
$$

subject to:

$$
\begin{aligned}
& c^{1}=w-\frac{b_{+}}{1+r}-\frac{b_{+}^{g}}{1+r}-s V\left(K_{+}, B_{+}\right) \\
& c^{2}=b_{+}+b_{+}^{g}+s W\left(K_{+}, B_{+} ; L_{+}, w_{+}^{e}\right) .
\end{aligned}
$$


The two constraints in (19) can be combined to imply:

$$
c^{1}+\frac{c^{2}}{1+r}=w+s\left(\frac{w}{1+r}-v\right)
$$

Problem (19) is unbounded, and the resulting demands incompatible with equilibrium unless the term in parantheses is zero:

$$
\mathrm{V}\left(\mathrm{K}_{+}, \mathrm{B}_{+}\right)=\frac{\mathrm{W}\left(\mathrm{K}_{+}, \mathrm{B}_{+} ; \mathrm{L}_{+}, \mathrm{w}_{+}^{\mathrm{e}}\right)}{1+\mathrm{r}} .
$$

We may verify from (5) that this condition is satisfied if the wage, interest rate and valuation function are in the suggested temporary equilibrium relationship.

When condition (21) is satisfied the young are indifferent about their portfolio composition among the two types of bonds and corporate equity. Solving problem (19) implies the value of the aggregate demand for financial instruments by the young is $\left(w-c^{1}(r, w)\right) L$. The aggregate value of their goods demand is $c^{1}(r, w) L$. Their labor is supplied inelastically.

Excess Demands of the 01d. As owners of the corporation, the old generation must choose labor demand and equity quality to maximize the sum of after-tax distributions and proceeds from resale of the equity interest. In other words, their problem is:

$$
\mathrm{L}^{\mathrm{D}, \mathrm{K}_{+}{ }^{\mathrm{B}}{ }_{+}, \mathrm{D}} \mathrm{Max}^{(1-\mathrm{t}) \mathrm{D}+\mathrm{V}\left(\mathrm{K}_{+}, \mathrm{B}_{+}\right)}
$$

where:

$$
D=F\left(K, L^{D}\right)-w^{D}-B+K-K_{+}+\frac{B_{+}}{1+r}
$$


Substitute (7) and (23) into (22) and derive first order conditions:

$$
\begin{aligned}
& \mathrm{F}_{2}\left(\mathrm{~K}, \mathrm{~L}^{\mathrm{D}}\right)=\mathrm{w} . \\
& \mathrm{F}_{1}\left(\mathrm{~K}_{+}, \mathrm{L}_{+}\right)=\mathrm{r} .
\end{aligned}
$$

from which:

$$
\mathrm{K}_{+}=\mathrm{K} *\left(\mathrm{r}, \mathrm{L}_{+}\right)
$$

Euler's Theorem applied again gives us the value of the objective function at an optimum of $\mathrm{W}(\mathrm{K}, \mathrm{B} ; \mathrm{L}, \mathrm{W})$ as defined by (18). This is the maximum the owners of the firm can realize, given $w$ and the inherited capital stock and debt obligation (and given the equity valuation function (7)).

In the solution to the maximization problem the financial policy is indeterminate. Given the other variables, a unit increase in $B_{+}$, resulting in a net distribution larger by $1-t$, leads to a reduction of $1-t$ in the market value of equity. The supply of corporate bonds may thus be arbitrarily set by the owners of the corporation. On the remaining markets they (the old) supply inelastically 100 percent of the ownership interest. They demand consumption goods amounting to the sum of $\mathrm{W}, \mathrm{B}$ and $\mathrm{B}^{\mathrm{g}}$. In addition they demand $\mathrm{K}_{+}$in the goods market for the corporation to carry into the next period.

Excess Demands of Government. Because we have chosen to consider the markets for labor, corporate bonds, equity, and goods, we do not need to give more consideration to the demands and supplies of the agent "government" than was involved in establishing the appropriate version of Walras' Law for this model. Ordinarily, the government does not appear on either side of any market except 
that for government bonds, the commodity we have chosen to drop from the dependent system of market clearing relationships.

Market Clearing. Having established excess demands of each of the agents we can proceed to the analysis of market clearing. The indifference of the young generation about portfolio composition and that of the corporation's owners about financial policy assures clearing of the equity and bond markets. The young purchase all of the equity in the corporation (at the price described by (7)) and all debt offered for sale by the corporation.

This leaves the labor and goods markets. Clearing of the labor market requires $L^{d}=L$, or, from (24):

$$
\mathrm{F}_{2}(\mathrm{~K}, \mathrm{~L})=\mathrm{w} \text {. }
$$

Equating demand and supply in the goods market implies:

$$
W(K, B ; L, W)+B+B^{g}+c^{1}(r, W) L+K *\left(r, L_{+}\right)=f(K, L)+K \cdot
$$

Use (18) to rewrite (28) as:

$$
\left(w-c^{1}(r, w)\right) L=K *\left(r, L_{+}\right)+B^{g}-t(F(K, L)-w L-B+K)
$$

quations (27) and (29) are the same as equations (1) and (2), from which we conclude that the latter do, indeed, describe the determination of wage and interest rate in temporary equilibrium, given expectations formed as described in the previous subsection. This completes the argument.

Uniqueness of Equilibrium. As noted above, the definition of equilibrium with rational expectations does not imply its uniqueness. We shall not attempt here to prove the uniqueness of the equilibrium of the model specified above. How- 
ever, we can show that what might loosely be described as the "conventional view" of valuation of the firm, in which each extra dollar of retained earnings is reflected in a dollar increase in equity value, will not be consistent with rational expectations in this model. For if this valuation rule prevailed agents would be led to demands incompatible with equilibrium. To express the conventional view we replace $V$ and $v_{+}^{e}$ above by $(1-t)^{-1}$ and $(1-t)^{-1} v_{+}^{e}$, cancelling the effect of the tax on equilibrium valuation as seen in (5) and (11). Now the anticipated valuation problem (13), after the ' substitution of $\mathrm{D}$ into the maximand, continues to have $\mathrm{B}_{++}$as an argument, with constant coefficient $-t\left(1+r_{+}^{e}\right)^{-1}$. The solution value $B_{+}=-\infty$ implies an infinite valuation of the firm by equity demanders, and an infinite supply of bonds by the young (individual borrowing to purchase stock). By the same reasoning with respect to problem (22), the owners of the corporation are led to an infinite supply of bonds, ruling out market clearing. The same sort of conclusion follows if $\mathrm{V}$ and $\mathrm{v}_{+}^{\mathrm{e}}$ are multiplied by any other constant different from unity.

\section{Commentary}

\section{Characteristics of Equilibrium Paths}

The analysis of section 3 demonstrates the assertion made in the introduction that the indifference between debt and equity characterizing financial policy in the absence of taxes in this no-uncertainty world continues to hold in the presence of the tax on distributions. The key to this conclusion is found in the equity valuation function (5), from which it follows that an extra dollar of retained earnings induces an increase of only $1-t$ dollars in the value of equity. 
The conclusion that the investment criterion of the firm $\left(K_{+}=K^{*}\left(r, L_{+}\right)\right.$) is unaffected by the tax on distributions is in itself not surprising, since without uncertainty all financing, and in particular, marginal financing can take the form of debt. Note, however, that this result holds even if the firm's owners do not consider financing the marginal investment through bonds. It is only required that the firm's potential shareholders compare the return on a dollar retained by the corporation and invested in capital with that on a dollar invested in bonds.

The implication that financial policy is indeterminate follows immediately from (5). We now go on to argue from (1) and (2) that the path of the economy through time is independent of the choice between debt and equity finance. From (2) it follows that the determinants of temporary equilibrium values of $\mathrm{w}$ and $\mathrm{r}$ include $\mathrm{B}$, the inherited corporate bond obligations, when $\mathrm{t}$ is positive. However, equilibrium depends also on $\mathrm{B}^{\mathrm{g}}$, the inherited government bond obligation. In the evolution of the economy these two types of debt are interrelated; a larger issue of corporate bonds in a period implies a larger corporate distribution, larger tax receipts and smaller issue of government debt. Using the government behavioral equation, $\mathrm{B}^{\mathrm{g}}=\mathrm{B}_{+}^{\mathrm{g}}(1+\mathrm{r})^{-1}+t \mathrm{D}$, and the definition (23) of $\mathrm{D}$, we conclude that the time path of $B^{g}+t B$ is independent of corporate financial policy (as represented by $\left.\mathrm{B}_{+}\right)$, since:

$$
\mathrm{B}_{+}^{\mathrm{g}}+\mathrm{tB}_{+}=\left[(1+\mathrm{r})\left(\mathrm{B}^{\mathrm{g}}+\mathrm{tB}\right)-\mathrm{t}\left(\mathrm{F}(\mathrm{K}, \mathrm{L})-\mathrm{wL}+\mathrm{K}-\mathrm{K} *\left(\mathrm{r}, \mathrm{L}_{+}\right)\right)\right]
$$

and it is this sum which enters the goods market clearing condition (2). 
The Effects of Changes in Parameters

The equations of temporary equilibrium with rational expectations allow us to analyze the effect of changes in the tax parameter or in government behavior, provided these are regarded as one-time changes which are not expected to recur. Thus, an unexpected increase in the tax rate will, according to (5) result in a loss of wealth (and hence consumption) for the old generation. If there is no change in the rate of interest, a five percentage point increase in the rate results in a loss equal to five percent of what their equity claims would have been worth in the absence of the tax. In general, we know from (2) that a change in $t$, given the values of the state variables, will lead to a change in the equilibrium values of $w$ and $r$, and consequently, a change in the future course of the economy. In this sense, the tax on distributions is not neutral. But the changes in the dynamic path derive not from substitution away from equity finance, rather from the wealth effects of the tax. An increase in the tax rate reduces the perceived wealth of the economy by reducing the value of equity. Equation (2) suggests the wealth effect may be equivalently viewed as a reduction in the extent to which government debt is regarded as wealth. An increase in the tax rate results in an increase in the implicitly expected debt retirement (by tax receipts) in the future.

Paradoxically, the implication that an increase in the rate of tax on distributions has the opposite effect on the path of the economy from an increase in government debt means that the latter may be the means not for shifting a burden to the future but for confining the consequences of an unexpected increase in exhaustive government expenditure to the old generation at the time it occurs. Consider an economy moving along a rational expectations equilibrium path with tax rate $t$, arriving at the time of the hypothetical moment of unexpected government 
expenditure with outstanding corporate and government debt obligations

$B$ and $B^{g}$. The government considers an increase in $t$ to meet the expenditure, which we shall assume has no effects which interact at any time with ordinary consumption in individual preferences. From (28) we know that an increase in $t$ of $d t$, ceteris paribus, creates a goods demand shortfall of $\mathrm{dt}(\mathrm{F}(\mathrm{K}, \mathrm{L})-\mathrm{wL}-\mathrm{B}+\mathrm{K})$ because it reduces by this much the value of equity with which the old generation had planned to finance consumption. This is the extra expenditure which can be undertaken by the government, diverting resources from old generation consumption, while maintaining goods market equilibrium. If this is financed by issuing the requisite amount of extra debt, financial market equilibrium will also be maintained. Suppose that in subsequent periods the government returns to its normal debt-managing role. Then the increased government debt will exactly offset the effects of the increased tax rate. In all real respects the path will be unchanged from the pre-extraordinary events path.

To see this note that the original path will continue to be an equilibrium one if in every period (from (2),

$$
d t(F(K, L)-w L-B+K)=d B^{g}
$$

Suppose this relationship holds in some period. Will it hold subsequently under the original rules of the economy's evolution? We have from the government behavioral equation:

$$
d t D+\frac{d B_{+}^{g}}{1+r}=d B^{g}
$$

We wish to show this implies 


$$
\operatorname{dt}\left(F\left(K_{+}, L_{+}\right)-w_{+} L_{+}-B_{+}+K_{+}\right)=d_{+}^{g}
$$

Substituting from (31) into (32) we have

$$
\mathrm{dtD}+\frac{\mathrm{dB}_{+}^{\mathrm{g}}}{1+r}=\mathrm{dt}(\mathrm{F}(\mathrm{K}, \mathrm{L})-\mathrm{wL}-\mathrm{B}+\mathrm{K}),
$$

from which, using the accounting relationship (23)

$$
\mathrm{dB}_{+}^{\mathrm{g}}=\mathrm{dt}(1+\mathrm{r})\left(\mathrm{K}_{+}-\frac{\mathrm{B}_{+}}{1+\mathrm{r}}\right)
$$

Now check that

$$
(1+r)\left(K_{+}-\frac{B_{+}}{1+r}\right)=F\left(K_{+}, L_{+}\right)-w_{+} L_{+}-B+K_{+} .
$$

This will hold if

$$
\mathrm{F}\left(\mathrm{K}_{+}, \mathrm{L}_{+}\right)-\mathrm{w}_{+} \mathrm{L}_{+}-\mathrm{rK}_{+}=0
$$

which we know to be true by Euler's Theorem along the original path.

Finally, we need to show that the new government debt, created to cover the extraordinary expenditure, amounts to $\mathrm{dB}^{\mathrm{g}}$ as defined in (31). Instead of the combination of changes $\mathrm{dt}, \mathrm{dB}^{\mathrm{g}}$, we make the combination $\mathrm{dt}, \mathrm{dB}_{+}^{\mathrm{g}}$, where, because of the tax, the latter depends upon the financial policy of the firm such that

$$
t D+\frac{\mathrm{dB}_{+}^{\mathrm{g}}}{1+r}=\mathrm{dt}(\mathrm{F}-\mathrm{wL}-\mathrm{B}+\mathrm{K}) .
$$

From (32) we see that this produces exactly the same situation in the next period as did the originally described pair of changes. The subsequent path of the economy thus continues to be an equilibrium. 


\section{Concluding Remarks}

The principle purpose of this paper has been to demonstrate that the double taxation of dividends characteristic of the classical corporation income tax need distort neither corporation financial nor investment policies. While the model embodies drastic simplifications, these have been designed to isolate the main point. The usual argument by which it is concluded that double taxation leads to distortion is developed in essentially the same setting. What is required is an extra tax on distributions; the presence or absence of other taxes has no bearing on the conclusion. This analysis, therefore, is sufficient to show where the previous reasoning goes wrong.

When the connection between the tax on distributions and the valuation of equity is taken into account it is seen that conclusions about the distorting effects of the corporation income tax based either on simple compounding of statutory corporation and individual income tax rates or on measured average tax rates using tax receipts are founded on incorrect premises. Both the continued existence of equity finance and the practice of making positive dividend payments may be fully consistent with maximization of stockholder wealth, even though dividends are subject to a tax and even though (in the model) capital gains are not taxed.

The picture of the incidence of the double taxation of dividends that results from spelling out its effects on asset prices is also somewhat surprising. While the precise incidence in this model is a function of government debt as well as tax policy, a major, if not the only, burden of a tax on distributions is borne by equity holders at the time the tax is instituted. A significant aspect of such wealth transfers is that they cannot be meaningfully reversed at a later date when the equity interests have changed hands. Removing the tax on dividends cannot restore the wealth of the original losers, 
but only provide a windfall gain to the new shareholders. These effects deserve careful consideration in attempting to understand such reforms as ful1 or partial integration of corporation and individual income taxes. 
FOOTNOTES

*Princeton University and National Bureau of Economic Research. This paper was written while I was a visiting fellow at the Center for Operations Research and Econometrics (CORE), Universite Catholique de Louvain, Belgium (January-June 1977), and an earlier version appeared as CORE Discussion Paper 7738, August 1977. I would like to express my appreciation for the exceptionally stimulating research environment at CORE as well as my thanks to UCL and the Commission for Educational Exchange Between the United States of America, Belgium, and Luxembourg for financial support. Discussions with William Andrews of Harvard Law School, Maurice Marchand and Henry Tulkens of CORE and Pierre Pestiau of the Universite de Liege, were of great help. Finally, thanks to Martin Hellwig, then of CORE and Princeton University, who went beyond the call of duty in reading drafts and educating me on the fine points of the theory of rational expectations.

1/ For a discussion of some of the problems and a suggested method to solve them see U.S. Government (1977).

2/ See also the follow-on papers by Stiglitz (1976), King (1975) and Asimakopulos and Burbidge (1975).

3/ There is a further difficulty with Stiglitz's representation of the provisions in U.S. tax law distinguishing return of capital from other distributions. Whereas, Stiglitz (1973, p. 9) makes this distinction a matter of the cumulative amount the owner has received from the corporation; in fact, it depends upon the relationship between cumulative earnings and cumulative distributions. Under the Stiglitz version, in effect, the first distributions represent return of capital while the U.S. law may be described as making the last distributions return of capital. 
4/ Using King's notation, the special case is that of $\mathrm{m}_{t}=0, z_{t}=0$, $t_{t^{\prime}}=0, \theta=1-t$, where $t$ is the rate of tax on distributions.

5f Diamond (1965) presents a model which includes government debt. Unlike the Diamond and Samuelson models, this model does not assume constant population growth, nor is the analysis confined to steady states.

6/ If population evolution were describable only by a higher order difference equation, additional state variables, in the form of a sufficient number of observations of past population levels to determine the solution of the difference equation, would be required. The basic argument would, however, be unaffected.

I/ To express this notion precisely, let $\mathrm{T}_{\mathrm{e}}$ (a) denote the set of possible successors to a as a result of temporary equilibrium, given expectations vector e. Formally, expectations will be described as rational if there exists a mapping, E, from the set of state vectors into the set of expectations vectors, such that for all possible state vectors, a, and all possible successor states, $a_{+}$in $T_{E(a)}(a)$, the expectations are correct, i.e., $E(a)=\left(w_{+}, r_{+}, v_{+}\right)$.

8/ King's (1974) analysis incorporates expectations concerning tax parameters and makes considerable use of various nonnegativity constraints. 
REFERENCES

Asimakopulos, A., and J.B. Burbidge, "Corporate Taxation and the Optimal Investment Decisions of Firms," Journal of Public Economics, IV (1975), $281-287$.

Diamond, Peter A., "National Debt in a Neoclassical Growth Model," American Economic Review, LV. (1965), 1126-1150.

King, Mervyn A., "Taxation and the Cost of Capital," Review of Economic Studies, XLI (1974), 21-35. , "Taxation, Corporate Financial Policy, and the cost of Capital:

A Comment," Journal of Public Economics, IV (1975), 271-279.

Muth, J., "Rational Expectations and the Theory of Price Movements," Econometrica, XXIX (1961), 315-335.

Samuelson, Paul A., "An Exact Consumption Loan Model of Interest With or Without the Social Contrivance of Money," Journal of Political Economy, LXVI (1958), 467-482.

Stiglitz, Joseph E., "Taxation, Corporate Financial Policy and the Cost of Capita1," Journal of Public Economics, II (1973), 1-34.

, "The Corporation Income Tax," Journal of Public Economics, V (1976), 303-311.

United States Government, Department of the Treasury, Blueprints for Basic Tax Reform, Washington, D.C., 1977. 